René Rác, Lucia Ludvigh Cintulová

ORCID: https://orcid.org/0000-0002-6448-0547

St. Elisabeth University of Health and Social Sciences, Slovakia

\title{
The Learning and teaching process of children from socially excluded communities
}

\begin{abstract}
The current problem of the low standard of the educational system for pupils from socially excluded communities is that it is not a flexible system and the primary schools do not only provide an educational but also a space to socialize for children. It is important to create a functioning education strategy that will not only respond to specific aspects of the personality of children from excluded communities, but will also be able to create a stimulating environment for them to develop. The emergence of socially excluded communities is the result of several factors; some examples are the low social status of families, low level of parental education and school aspects in the locality where primary school is associated with segregation. The social development of children from an early age is influenced by the family and the environment where their education takes place.
\end{abstract}

\section{Keywords}

Social excluded communities. Teaching Roma children. Personality of the Roma children. Educational strategy. 


\section{The socially excluded community}

The article focuses on problems of the socially excluded localities and pupils attending primary school. At birth, no individual has the opportunity to freely decide which environment he or she will be born into, how he or she will be educated, or what family customs will be followed. In adulthood, we have a free choice in which direction we want to go, whether our family codes suit us and whether we want to do something about that or not. From birth, each individual acquires the habits of his ancestors, which affect education and integration in the school environment, respect for school attendance, as well as future professional development. Socially excluded localities often offer a negative approach to life goals, where the child lacks a quantitative pattern of behavior for his future study and professional life, which at the same time affects integration into the majority population. A long-term discussed phenomenon in national politics is the analysis for active tools that will be a beneficial indicator of a positive change in public attitudes towards young people from socially excluded localities. This is the strategy of the educational system and in it we find possible changes that need to be focused on to improve the quality of education for all individuals.

The socially excluded community is characterized by a place and a part of the municipality where large families with children at risk of absolute social exclusion, are inhabited by the majority society. These people are dependent on social and financial benefits due to long-term unemployment. The family's housing unit is in a desolate state and is only partially equipped to provide essential living needs for the personal or internal development of the individual. Inspite of the predominance of negative elements when describing the socially excluded locality and the way of living, we can also point out the positive, which is cohesion and mutual help in family communities, where they live together in one locality.

Sýkora and Matoušek mutually agree that „this is an involuntary exclusion of the population of the socially weak, who found themselves in an unfavorable and unexpected situation, which could have a rapid decline or gradual development resulting in exclusion. „These localities are created not only on the basis of the market allocation of housing, but their origin is often due to the practices of municipalities in allocating social housing. ${ }^{{ }^{1}}$

${ }^{1}$ Cf. L. Sýkora, Rezidenční segregace, Praha 2010: Univerzita Karlova v Praze, Př́rodovědecká fakulta, p. 20. 
Budayová $^{2}$ argues that the socializing effect of Roma family education on their children may be different in socially excluded communities, as it is in these communities that there are obviously different types of social exclusion.

Some areas of socially excluded localities do not only have the structure of the Roma population, but the already mentioned structure of ghettos. The locality is not only on the fringes of society, but also faces other problems that strengthen the internal structure, rules and economic management. Romani culture is known to be not only a large family, but also an energetic, emotionally subdued and strongly family-based culture. In an excluded locality, one cannot expect that there are no conflicts, but the situation almost always calms down spontaneously and in times of unfavorable situations, the family shows maximum cohesion. ${ }^{3}$

Pathological phenomena are part of the unfavorable social situation that prevails in the excluded locality. Usually, there is a measure of criminal activity, usury and abuse of the social system in the localities. „The emergence of socially excluded localities is the result of the displacement of the socially weaker from the majority society and takes place with the knowledge of cities or often on the basis of their own decisions." ${ }^{4}$

The structure of the socially excluded locality is based mainly on the population of Roma origin for decades. The strongly rooted personality characteristics of the population determine the life development of the individual. The lack of motivation, disappointment and distrust of the older generation has an impact on the lives of the younger generation, which has an obligation to attend school. The problem is not only poverty, but a strong influence on the individual, whose educational needs are negatively affected. Most students do not have the opportunity to do their homework properly and on time, as they have to take care of several younger siblings. There are several rules in Roma settlements that are typical of social exclusion, and these are naturally followed. The girl has a duty to cook, clean, and take care of the family environment. The son is the father's right hand, the future head of the family. In most cases, when a child

2 Cf. Z. Budayová, Sociálne neprispôsobiví občania v intenciách sociálnej práce, Ružomberok 2019: Verbum vydavatel'stvo KU, p. 4.

${ }^{3}$ Cf. I. Gabal, Dlouhodobý monitoring situace romských lokalit v ČR - České lokality. Závěrečná zpráva, Praha 2010: Úřad vlády ČR, p. 22.

${ }^{4}$ Cf. I. Gabal, Dlouhodobý monitoring situace romských lokalit v ČR - České lokality. Závěrečná zpráva, Praha 2010: Úřad vlády ČR, p. 20. 
comes home from school that automatically carries out activities, which are set up in the family.

\subsection{A socially disadvantaged pupil from an excluded locality}

Jan Průcha deals with the situation of socially disadvantaged students and defines them as: „students who do not have the same opportunities for education as the majority population of pupils (students), mainly due to unfavorable sociocultural conditions of their families or other environments in which they live. "“

Slowík has long dealt with social disadvantage, which has an impact on pupils' learning. In his publications, the exact influence of racial and ethnic differences is visible, including the literary, grammatical barrier, the cultural and economic status of the family, a different upbringing, and the low social status of the individual. Evaluation of the problem of socially disadvantaged students is an extended continuity of socio-cultural issues, where we see considerable anachronism. ${ }^{6}$

Social development is influenced from an early age by the family and the environment where the education takes place. At present, we can also talk about an important factor in the media that interferes with the education system. Socially disadvantageous factors that manifest themselves in students can be effectively evaluated by observation. Factors are visible in the environment or in relation to another environment that is socioculturally different from the majority society. We find here a different and especially weakened function of healthy development, affecting the development of an individual's personality.

Authors Ihancík and Špitka present the characteristic elements of a socially disadvantaged pupil as follows: "it is a child whose parents are uneducated or have attained a low level of education, or a child from an incomplete family and a family with low income with parents with no qualifications or family members with long-term unemployment. There is a low standard of the family and housing where education takes place, possible belonging to a minority and a possible combination of these factors. According to the above characteristics, Roma children can usually be considered socially disadvantaged."

${ }^{5}$ Cf. J. Průcha, E. Walterová, J. Mareš, Pedagogický slovník, Praha 2009: Grada, p. 449.

${ }^{6}$ Cf. J. Slowík, Speciální pedagogika: prevence a diagnostika, terapie a poradenství, vzdělávání osob s rưzným postižením, člověk s handicapem a společnost, Praha 2007: Grada, p. 147.

Cf. D. Knotová, Školní poradenství, Praha 2014: Grada, p. 183. 


\subsection{The strategy of the educational system}

The strategy of the educational system presents beneficial conditions for pupils who are from a socially disadvantaged locality. ${ }^{8}$ This system is used mainly for future schoolchildren and for students who are interested in studying, knowledge and career development. These children can attend preparatory class that help children from the social exclusion to get integrated in school systém, but at the same time the legal representative participates in the work performance, which he duly observes. It is also recommended that the preparatory school should be attended by children from socially excluded localities who suffer from a speech disorder. ${ }^{9}$

Davidová ${ }^{10}$ deals with the education of Roma pupils from socially excluded localities, pointing out the following educational strategies:

- preparatory class for socially disadvantaged pupils with the support of a personal assistant,

- strategies for social support for teachers and the school environment,

- school climate,

- support of a pedagogical worker.

Tomanek ${ }^{11}$ figured out that the family plays a key role in the successful integration of Roma people in the community, into society and in the labor market. Education is also a very important factor influencing the future involvement in life, job placement and society.

Vágnerová ${ }^{12}$ points out the possibilities that can be helpful for the education of pupils from socially excluded localities:

- The influence and actions of the pedagogical worker (class teacher), the teacher knows the child's environment,

- Cooperation with a special pedagogical center (determination of an individual educational plan, evaluation, determination of a future educational goal, including methods, models/forms),

${ }^{8}$ Cf. J. Němec, Vzdělávání žáků se sociálním znevýhodněním, Brno 2009, p. 13.

9 Cf. J. Němec, Včela má pilu, aneb, Př́pravné třídy pro děti ze sociálně znevýhodněného prostředí, Brno 2005, p. 34.

${ }^{10}$ Cf. E. Davidová, Kvalita života a sociální determinanty zdraví u Romů v České a Slovenské republice, Praha 2010: Triton, p. 111.

${ }^{11}$ Cf. P. Tománek, Fragmenty rodiny: manželstvo a rodina v súdnej sieni, Brno 2019: Tribun, p. 284.

${ }^{12}$ Cf. M. Vágnerová, Vývojová psychologie: dètství a dospívání. Praha 2012, pp. 57-60. 
- Cooperation with a special pedagogue, pedagogical-psychological counselling,

- Knowledge of the preventive program of the school,

- Active cooperation with an educational counselor and a methodology for the prevention of juvenile delinquency,

- Active cooperation with the department of social and legal protection of children.

Přinosilová ${ }^{13}$ defines the following tools which may be helpful for the education of pupils from socially excluded localities:

- Counseling in the place of the excluded locality (tutoring, legal advice, organization of free time);

- Local transport to the school (pick-up, drop-off);

- Roma assistants working at school.

Tomek and Tancošová ${ }^{14}$ participated in a research strategy for the education of socially disadvantaged and excluded pupils and recommend the following:

- Possibility of an optional subject Roma language

- Support system for transition and change of the educational school institution

- Involvement of legal representatives in the school prevention programmes

- Professionals with pedagogical skills and education in social work

- Regular lifelong education of pedagogical staff

- Special team of pedagogical staff for gifted students (music, singing, dancing)

- Interweaving of cultures

- Public events, school meetings

- Cooperation with the police.

${ }^{13}$ Cf. D. Přinosilová, Vybrané okruhy speciálně pedagogické diagnostiky a využití v praxi speciální pedagogiky, Brno 1999: Masarykova Universita Brno, p. 74.

${ }^{14}$ Cf. K. Tomek, A. Tancošová, Strategie pro zlepšení vzdělávání romských dětí. Romové a sociální pedagogika, Ústí nad Labem 2001: Hnutí R, pp. 9-11. 


\subsection{Reasons of failure in the education of Roma pupils and possible solutions}

Currently, in the Czech Republic we can meet the most socially excluded population, namely the Roma, in society. Prejudices against this minority have been ingrained since ancient times. When a child hears repulsive/disagreable/unsightly and imaginary things about this ethnic group that persons around him claim, he immediately develops the attitude that the Roma are a bad people. This perception manifests itself in the behaviour with their classmates, and this can then lead to a bad atmosphere at school..$^{15}$

Factors which contribute to the failure of pupils from socially excluded localities of Roma origin at school, are classified as internal and external. The endogenous influence of a poor physical condition and the influence of the psyche are the result of a weakened mental level, which is part of the lack of readiness of students. Among the exogenous factors that affect a socially disadvantaged pupil, we rank primarily the influence of the family and the family environment. Many times, Roma citizens do not receive an education that is congruent with their vision for life. The reason for this is not only due to the bad influence of exogenous factors, but alsobecause of the influence and power of state institutions, which provide a system of financial support for unemployed, socially excluded people, who jointly create and inhabit localities where they then congregate. These localities have a significant impact on the pupils' success at school and on their education. However, exogenous factors do not only have a negative impact. The school environment, which can influence at least part of the student's thinking, can have a positive effect and be a formula for their success at school. ${ }^{16}$

According to Budayová ${ }^{17}$, education for the Roma minority is important due to the low potential of parents to teach their children, but also due to the negative outlook on the future.

Part of the cause of ignorance of socially excluded students can be explained by theories justifying failure in the educational process:

Biological-genetic theory: a theory based on ethnic differences. Each ethnic group holds its cultural status, values and patterns of education, which

\footnotetext{
${ }^{15}$ Cf. P. Navrátil, Romové v české společnosti, Praha 2003: Portál, p. 148.

${ }^{16}$ Cf. M. Kovaříková et al., Pedagogicko-psychologická problematika romských žáků ve vztahu k jejich školní úspěšnosti, Ústí nad Labem 1998: Portál, p. 57.

${ }^{17}$ Cf. Z. Budayová, Social exclusion of the Romaethnic group in the interests of social work, Warszawa 2017: Fundacja, p. 11.
} 
it strives to pass on to younger generations. It is known among the Roma population that when an individual goes in a different direction than the one determined by the biological-genetic theory, they are still excluded due to their Roma nationality.

Socio-economic theory: we classify poverty as one of the main factors connected with socially excluded localities. The unfavorable social and financial situation clearly affects the healthy development of the individual, which also has an impact on the school environment when joining the class. Pupils are often despised by other classmates who do not know this relationship. The pedagogical worker must intervene as early as possible in this difficult situation and take preventive measures, so that the child is included in any class/activities. Pupils who suffer from poverty are more likely to engage in delinquent behavior as a result of pathopsychological phenomena. ${ }^{18}$

Cultural theory: Cultural theory emphasizes the difference between language and cultural minorities. The difference in the language that the family speaks at home in socially trained localities, is a natural means of communication, but there is a demonstrable language barrier in the education of socially weaker pupils. Cultural language diversity is an almost inevitable process in a community where a child grows up from birth. Pupils have adequate knowledge of verbal communication (articulated speech, formation of sounds, words and sentences) however, language and communication in different spheres of cultural and social environment is greatly limited by the diversity of linguistic communication of abstract concepts. ${ }^{19}$

Every pupil, regardless of their affiliation or social inclusion, has the opportunity to model and redress this problem/barrier, thanks to similar language patterns, word order dynamics, variety and the extensive communication potential offered by society outside the socially excluded locality. ${ }^{20}$

${ }^{18}$ Cf. O. Matoušek, H. Pazlarová, Hodnocení ohroženého dítěte a rodiny: v kontextu plánování péče, Praha 2014: Portál, p. 153.

${ }^{19}$ Cf. D. Fontana, Psychologie ve školní praxi: př́ručka pro učitele, Praha 2010: Portál, p. 35.

${ }^{20}$ Cf. J. Kelnarová, E. Matějková, Psychologie a komunikace pro zdravotnické asistenty: 4. ročník, Praha 2009: Grada, p. 77. 


\section{Aims and methods}

The research used a combination of two qualitative tools - an interview and a case study of a student from a socially excluded locality. The data collection were done by May 2019.

The main aim of the research was to find out the influences that affect the education of a pupil from a socially excluded locality, and the possibilities of the educational process.

The subject of the qualitative research is a pupil in the second stage of the primary school in Karviná.

\subsection{Research sample}

Case study: Lenka* year of birth: 2006 / 8. Class: primary education

Family and social anamnesis

Thirteen-year-old Lenka lives with her parents in a low cost flat, which they have recently moved into. The father has been unemployed long-term and abuses tobacco products and alcohol. He lost his job as a miner as a result of a very poor work ethic, non-fulfillment of work duties and neglect of working hours. The child's mother is unemployed, without any official education and never worked before motherhood. The mother has been apprehended several times for assaulting strangers. The family does not respect the law and is in conflict with the majority society. The mother is of the opinion that the woman should not work, but take care of the household, and the father is the main actor of the family as the leader. Thirteen-year-old Lenka comes from a family with a very weak financial situation. She lives in a small room with nine siblings.

\section{School anamnesis}

Thirteen-year-old Lenka has been attending primary school since the first grade. The girl suffers from a speech disability of moderate severity. Her classmates make fun of her for being overweight. The classmates reject the girl and do not cooperate with her. The girl thinks that this is due to her being of Roma ethnic origin. When the girl asks for help withher school work her parents refer her to her older siblings who do not know the right methods/techniques and 
procedures for learning. Therefore, she refuses to learn and prepare for her lessons. After school, the girl regularly meets up with a Roma social services assistant, who tries to prepare her for her classes. The girl suffers from impaired concentration, short-term memory and attention deficit disorder. The girl is of the opinion that learning is not a suitable choice for her, and she will be very happy to graduate from primary school. The girl refuses to learn, and if there is a situation of conflict with the teacher, sheends the conversation with the argument that the man is the main breadwinner of the family and she will take care of her children. The girl has a problem with mathematics and in reading the Czech language. The girl does not do her homework unless she is with the Roma assistant who helps her. The mother is of the opinion that "that's what school is like“. The pedagogical staff evaluates Lenka as being average, does not show interest in self-education and is sometimes rude. The family does not go to class meetings and they do not show any interest in the girl's schooling. Lenka's absence is above average, the reason being the lack of funds for transport to school or her having to stay home to help with domestic duties. Notes excusing her from school have been written by legal representatives or by doctors citing "nausea" as the reason for her absence. During the observation, it was found that the girl is interested in creative activities. Her hobbies include painting, modeling with ceramics, dance, music, and singing.

\section{Personal anamnesis}

The girl appears to have a strong personality who doesn't like anything at school. She is positive, and smiling. She is helpful with the family, and respects her father. Lenka relates to her mother as a friend to whom she can say everything. In her free time, she visits the low-threshold facility Oáza, where she likes to make creative things. Lenka finds it hard to adjust if there is a change of staff at school, in the low-threshold facility or in a hostel. The girl has a favorite worker in the center, in whom she confiders. This girl has a problem with trusting others and makes friends with the wrong types. Lenka wants to be a cook in the future, but she is not interested in studying. She thinks that her mother can still cook well without having had any schooling. The girl misses out on school trips and other school events. 


\section{Results}

Interview with the respondent working at primary school in Karviná:

1. What effect does the low standard of living have on the pupil's education? „Personally, I observe that students who are from a lower standard of living or from an excluded locality refuse to talk to Lenka."

2. What are the typical reasons that have a negative effect on the student and her / her benefit?

„Lenka's behaviour? Well, she's good at that; she's not serious. Except for the opinions she brings from home, of course."

3. Do you know what environment the student comes from? Does the environment in which she grows up influence the student's behaviour?

"She comes from the worst! Terrible. An eternally indebted family that does not have enough money and is also burdened by usury."

4. How do you assess the pupil's attitude towards education; coming from a socially excluded locality or from an ethnic minority and socio-culturally disadvantaged?

„Lenka does not show any interest in her education. She is of her mother's opinion that she should take care of the household!"

5. What are the chances of success of your student who lives in a socially excluded locality, to achieve a good quality education?

„I have some hope for the other students; at least fifty percent. For Lenka? Zero!" She is of the opinion that she will be financed by the state, and will receive material benefits from the new housing allowance. Although Lenka has the option of free tutoring, she does not seem interested.

\section{Discussion}

What effect does the low standard of living have on the pupil's education? Low standards of living, the upbringing and the environment affect the education of pupils. The difference in the environment in which the child grows up, together with the factor of social exclusion, have a clear effect on the child's disadvantageat school. A low standard of living together with her family's negative attitude towards education influence the quality of results which the pupil obtains. The goal of every teacher is to convey good quality information at the 
time of teaching. The information is targeted and intentional, and it has a systematic effect on the pupil. At XXX, Karviná primary school, most pupils with not good school results are under the supervision of a special pedagogue and psychologist. The situation at the school is relatively complicated, mainly due to the lack of staff, specifically assistants. The main reason is the lack of money to cover their costs. In an interview with the pedagogue, who works with a group of pupils with problems, he expressed his opinion that the environment has a negative impact on students. Possibly, for the education of the pupil to be successful, there needs to be a change in the environment and housing. This could lead to motivation and development. From the research questions and answers, he evaluates the influence of the native environment and low standards of living as a negative influence that undermines the education and training of the student.

What are the typical factors that have a negative effect on students and their benefits?

The interviewed respondent of the primary school in Karviná gives the following reasons: inconsistency, and broken families that are not interested in making goals for the future or having a career. The respondent is of the opinion that the source of the student's behaviour is the bad upbringing. Through this question, the researcher also observes the respondent's inability tobe aware that teaching with inappropriate methods may be a cause of indiscipline in class; a pupil who is not oriented to teaching shows boredom and lack of interest in the subject. Research results confirmed the fact that these may be inflexible, abstract, pedagogical methods that students do not master. Last but not least, the answers given in the research cannot be ignored, namely the segregation of families which have a low potential for education. A bad family background and pattern has a negative influence on the school results, especially if the pupil comes from a socially excluded locality.

Do you know the environment the student comes from? Does the environment in which the student grows up influence the student's behavior? The reasons for pupils' pathological behavior, including a very poor education, are a common problem in the environment where the child comes from, where he grows up and who he is surrounded by. Individual aspects of socially disadvantaged pupils also have an effect on the personal growth of individuals. 
No one chooses the environment in which he is born and by whom he will be brought up. The environment shapes the personality of each student. It is the key to social inclusion in society. The relationships that are offered to the child by the environment, reflect the future. Based on the research, I conclude that the students come from a negative environment. Housing is not adapted to the excessive number of inhabitants in the household, so it cannot offer a personal space for each individual. The research also found that the environment, specifically the household in which he or she grows up, has a significant effect on the pupil. Last but not least, the influence of the father's behavior towards the mother - when there is a model of superiority of the male - is another important factor in the environment.

How do you assess the attitude towards education of a pupil from a socially excluded locality, from an ethnic minority or who is socio-culturally disadvantaged?

The attitude of each pupil is definitely influenced by the social environment, which insufficiently equips the child with the competencies that need to be applied, starting with the first grade. And this is where the turning point comes; when the teacher can set the atmosphere and adopt the appropriate/positive school environment which will have an impact on the student for the distant future. At the beginning, the pupil's attitude is influenced by the language barrier because these children do not have the opportunity to acquire language competences. They speak more Czech-Romani and therefore feel alone due to their difficulty to understand the language being spoken around them.

What is the chance ofyour student who lives in a socially excluded locality to achieve a good quality education?

In this research question, the pedagogical worker points to the success of education (OR lack of success) especially to the factor of the social system in the Czech Republic. The system is inadequately set up. It demotivates pupils in the transition from primary to secondary education and thus also from contining their studies. The system of providing benefits enables material and financial security for survival in life and therefore, one of the consequences of this security is that students do not show any interest in education because they have no motivation to make a living for themselves. The research and answers given 
show that, despite the unfavorable social situation she (Lenka) is experiencing, the student has the opportunity to study, including going to university.. It is a quality type of financial support, which offers the development of mental abilities and, if necessary, tutoring to fill in gaps which the students might have. However, students often refuse to use the support system provided and instead present with negative resistance.

\section{Conclusion}

In conclusion, it is not possible to decide unequivocally whether today's youth are worse or better off than the previous generations. We can descibe today's children as children living in different times and influenced by other factors especially the weakened social background. However, it is important to know that they are still "children“ who need the help of professionals, so let us teach them the ability to overcome obstacles and pitfalls. What we instil into the child, we can expect to get back in our interactions with them (as we live our life together).

\section{Bibliography}

Bartoňová M., Bytešníková I., Vítková I., Děti se speciálními vzdělávacími potřebami $v$ mateřské škole: texty k distančnímu vzdělávání, Brno 2012: Paido.

Budayová Z., Social exclusion of the Romaethnic group in the interests of social work, Warszawa 2017: Fundacja Art przeciw przemocy.

Budayová Z., Sociálne neprispôsobiví občania v intenciách sociálnej práce, Ružomberok 2019: Verbum vydavatel'stvo KU.

Davidová E., Kvalita života a sociální determinanty zdraví u Romů v České a Slovenské republice, Praha 2010: Triton.

Fontana D., Psychologie ve školní praxi: příručka pro učitele, Praha 2010: Portál.

Gabal I., Dlouhodobý monitoring situace romských lokalit v ČR - České lokality, Závěrečná zpráva, Praha 2010: Úřrad vlády ČR.

Kelnarová J., Matějková E., Psychologie a komunikace pro zdravotnické asistenty: 4. ročník, Praha 2009: Grada.

Knotová D., Školní poradenství, Praha 2014: Grada.

Kovaříková M. et al., Pedagogicko-psychologická problematika romských žáků ve vztahu k jejich školní úspěšnosti, Ústí nad Labem 1998: Univerzita Jana Evangelisty Purkyně 
v Ústí nad Labem.

Matoušek O., Pazlarová H., Hodnocení ohroženého ditěte a rodiny: v kontextu plánování péče, Praha 2014: Portál.

Navrátil P., Romovév české společnosti, Praha 2003: Portál.

Němec J., Vzdělávání žáků se sociálním znevýhodněním, Brno 2009: Paido.

Němec J., Včela má pilu, aneb, Př́pravné třídy pro děti ze sociálně znevýhodněného prostředí, Brno 2005: Masarykova univerzita v Brně.

Průcha J., Mareš J., Walterová E., Pedagogický slovník, Praha 1998: Portál.

Průcha J., Walterová E., Mareš J., Pedagogický slovník II., Praha 2009: Portál.

Přinosilová D., Vybrané okruhy speciálně pedagogické diagnostiky a využití v praxi speciální pedagogiky, Brno 1999: Masarykova Universita Brno.

Slowík J., Speciální pedagogika: prevence a diagnostika, terapie a poradenství, vzdělávání osob s různým postižením, člověk s handicapem a společnost, Praha 2007: Grada.

Sýkora L., Rezidenční segregace, Praha 2010: Univerzita Karlova v Praze, Př́rodovědecká fakulta.

Tománek P., Fragmenty rodiny: manželstvo a rodina v súdnej sieni, Brno 2019: Tribun.

Tomek K., Tancošová A., Strategie pro zlepšení vzdělávání romských dětí. Romové a sociální pedagogika, Ústí nad Labem 2001: Hnutí R.

Vágnerová M., Vývojová psychologie: dětství a dospívání, Praha 2012: Karolinum. 